\title{
Implementasi Metode Deteksi Tepi Laplacian dan Jarak Euclidean untuk Identifikasi Tanda Tangan
}

\author{
Mas Aly Afandi*, Sevia Indah Purnama dan Risa Farid Crisianti \\ Fakultas Teknik Telekomunikasi dan Elektro, Institut Teknologi Telkom Purwokerto, \\ Banyumas, Jawa Tengah, Indonesia \\ *Corresponding author, e-mail: aly@ittelkom-pwt.ac.id
}

\begin{abstract}
Abstrak - Tanda tangan adalah salah satu biometrik yang banyak digunakan untuk autentikasi dan verifikasi dokumen penting. Keberadaan tanda tangan sebagai bentuk pengesahan dan persetujuan dalam dokumen-dokumen penting adalah hal yang wajib. Seiring perkembangan teknologi saat ini, proses penandatanganan dapat dilakukan dalam media digital seperti handphone maupun media lainnya. Kemampuan sistem untuk mengidentifikasi tanda tangan seseorang menjadi penting karena banyak pemalsuan yang terjadi. Penelitian ini bertujuan untuk mengimplementasikan metode deteksi tepi Laplacian dan jarak Euclidean untuk mengidentifikasi tanda tangan seseorang. Total citra yang digunakan yaitu 20 tanda tangan dari 10 orang yang berbeda dimana 15 tanda tangan sebagai data citra latih dan 5 tanda tangan sebagai data citra uji. Hasil penelitian ini menunjukkan bahwa metode deteksi tepi Laplacian dan jarak Euclidean memiliki akurasi sebesar 94\% dengan 1 ketetanggaan, dengan 2 ketetanggaan memiliki akurasi sebesar $60 \%$, dan memiliki akurasi sebesar $74 \%$ dengan 3 ketetanggaan.
\end{abstract}

Kata Kunci : tanda tangan, deteksi tepi Laplacian dan jarak Euclidean

\begin{abstract}
Signature is one of the biometrics that are widely used for important document authentication and verification. The existence of a signature as a form of validation and approval in important documents is mandatory. Along in current sophisticated technological developments, signing can be done using digital media such as cellphones or other media. The ability of the system that can be identify a person signature is important. This research aims to implement the Laplacian edge detection method and Euclidean distance to identify a person signature. The total image that used is 20 signatures from 5 different people while 15 signatures as data training image and 5 signatures as a data test image. The result of this research indicate that Laplacian edge detection method and Euclidean distance have an accuracy of $94 \%$ with 1 neighbor, with 2 neighbor has an accuracy of $60 \%$ and has an accuracy of $74 \%$ with 3 neighbor.
\end{abstract}

Keywords : signature, Laplacian edge detection and Euclidean distance

\section{Pendahuluan}

Biometrik adalah penetapan identitas seseorang berdasarkan sifat atau perilaku yang melekat pada orang tersebut. Pengenalan biometrik dapat didefinisikan sebagai ilmu yang membangun atau memetakan identitas seseorang berdasarkan karakter dan perilakunya [1]. Sifat dari biometrik yaitu melekat pada individu itu sendiri sehingga sangat sulit untuk memanipulasi atau melupakan sifat-sifat yang melekat pada diri individu tersebut [2]. Sifat tersebut membuat pengenalan biometrik merupakan solusi yang dapat di andalkan untuk mengidentifikasi pengakuan atau persetujuan dari seorang individu [3].

Berdasarkan sifatnya, sistem biometrik dibagi menjadi dua yaitu pengukuran biometrik yang bersifat fisik dan bersifat perilaku. Sidik jari, garis tangan, wajah, iris dan retina adalah biometrik yang bersifat fisik sedangkan tanda tangan, tulisan tangan, dan cara berjalan adalah biometrik yang bersifat perilaku [4]. Sistem biometrik yang bersifat perilaku terutama tanda tangan adalah sistem biometrik yang banyak digunakan di Indonesia.

Tanda tangan memiliki peranan penting dalam pengesahan dan persetujuan di berbagai dokumen penting. Sebuah dokumen dianggap sah apabila terdapat tanda tangan dari seseorang yang berwenang untuk mengesahkannya. Proses penandataganan dokumen penting itu sendiri dilakukan menggunakan pensil maupun pena. Perkembangan teknologi saat ini memungkinkan penandatanganan dokumen penting dalam bentuk 
digital. Proses penanda tanganan dapat dilakukan dari sebuah handphone maupun pen tab [5].

Penggunaan tanda tangan digital sebagai bentuk persetujuan tanda terima maupun persetujuan surat berharga sudah mulai diterapkan [6]. Berbagai masalah terjadi dari penerapan teknologi ini, salah satunya adalah pemalsuan tanda tangan [7][8][9] [10]. Masalah pemalsuan tanda tangan dapat merugikan banyak pihak. Hal ini terjadi karena pada teknologi tanda tangan digital belum memiliki sistem pengenalan tanda tangan sehingga pemalsuan tanda tangan dapat terjadi. Berbagai masalah tersebut mendorong penelitian tentang pengenalan tanda tangan menjadi topik yang penting untuk dikembangkan [11][12][13].

Penelitian ini bertujuan untuk mengembangkan sebuah metode pengenalan tanda tangan. Metode yang di usulkan memiliki keunggulan di sisi prosess yang cukup cepat sehingga dapat digunakan pada komputer dengan spesifikasi rendah. Hasil dari penelitian ini diharapkan mampu menjadi dasar bagi terciptanya sistem tanda tangan digital yang lebih baik.

\section{Metode}

\subsection{Citra digital}

Citra digital adalah representasi dari sinyal 2 dimensi. Citra digital didefinisikan sebagai fungsi $f(x, y)$ dimana $\mathrm{x}$ dan y adalah koordinat di ruang spatial yang berisikan nilai warna dengan ukuran resolusi $\mathrm{M}$ baris dan $\mathrm{N}$ kolom. Mengolah citra digital dapat diartikan mengolah sinyal dalam 2 dimensi pada baris dan kolomnya dengan tujuan untuk mempermudah interpretasi oleh manusia maupun mesin. Pengolahan citra dilakukan dengan memanipulasi nilai pixel maupun transformasi citra sehingga dapat di ubah menjadi ke ruang yang berbeda.

Picture element, image element, atau piksel adalah bagian terkecil dari suatu citra. Citra dengan spektrum warna 8 bit akan memiliki rentang nilai piksel dari 0 hingga 255 dengan 0 adalah warna hitam dan 255 adalah putih. Citra juga memiliki kanal warna dasar yang membentuknya, secara umum kanal warna dasar dari suatu citra terdiri dari merah, hijau dan biru sehingga dikenal dengan citra RGB. Pengolahan citra memungkinkan untuk memproses sebuah citra digital dengan 3 kanal menjadi hanya 1 kanal saja. Proses mengubah citra yang memiliki 3 kanal menjadi 1 kanal dilakukan degan mendapatkan derajat keabuan atau disebut dengan nilai grayscale. Pengolahan citra dari RGB menjadi citra abu-abu dilakukan dengan tujuan mengurangi banyaknya piksel yang akan diproses, sehingga mempermudah proses perhitungan maupun transformasi yang dilakukan dalam mendapatkan hasil yang di inginkan.

$$
g(x, y)=0,2989 * R+0,5870 * G+0,1140 * B
$$

Mengubah citra RGB menjadi citra grayscale dapat dilakukan dengan penerapkan persamaan (1) dimana nilai piksel dari kanal merah dikalikan dengan 0,2989 sedangkan nilai piksel dari kanal hijau dikalikan dengan 0,5870 dan nilai piksel dari kanal biru dikalikan dengan 0,1140 .

Citra biner adalah jenis citra digital yang memiliki kemungkinan piksel 0 dan 1 . Citra ini disebut juga citra hitam putih.

$$
\begin{aligned}
& b(x, y)=1, g(x, y)>t h \\
& b(x, y)=0, g(x, y)<t h
\end{aligned}
$$

Citra biner dibentuk dengan menentukan batas ambang untuk nilai piksel dari citra grayscale. Berdasarkan persamaan (2) didapatkan bahwa ketika nilai piksel dari citra grayscale melebihi dari nilai batas ambang, maka nilai piksel untuk citra biner di koordinat $x$ dan y yang sama adalah 1 . Nilai piksel citra biner akan bernilai 0 jika nilai piksel dari citra grayscale kurang dari nilai batas ambang yang telah ditentukan [14].

\subsection{Deteksi tepi Laplacian}

Deteksi tepi adalah salah satu metode untuk mendapatkan bentuk dari suatu objek. Penelitian ini menerapkan metode deteksi tepi Laplacian. Metode Laplacian memanfaatkan operator derivatif kedua dimana operator ini digunakan untuk mendeteksi kondisi dari nilai intensitas cahaya yang menyentuh titik nol saat fungsi berpindah dari nilai positif ke negatif (zero crossing). Desain dari deteksi tepi Laplacian dilakukan dengan merepresentasikan citra input sebagai citra 1 kanal dengan fungsi step.

$$
j(n)=U(n)
$$

Fungsi step merupakan fungsi yang bernilai 1 saat nilai $n$ lebih besar atau sama dengan 0 , dan akan bernilai 0 saat nilai $\mathrm{n}$ kurang dari 0 .

Citra yang telah direpresentasikan menjadi fungsi step ditambahkan dengan derau putih Gaussian dengan nilai rata-rata 0 dan variance $\partial_{b}^{2}$, dengan tidak memperhitungkan spesifikasi lain low pass filter akan memiliki response impulse yang terbatas $v(n),-M \leq n \leq M$. 


$$
\sum_{n=-M}^{M} v(n)=1
$$

Filter tepi yang digunakan untuk mendeteksi kondisi zero crossing akan menghasilkan perbedaan yang maksimum pada output dengan posisi $\mathrm{n}=-1$ dan $\mathrm{n}=0$. Filter ini memiliki nilai $v(0)$ yang sangat besar.

$$
\partial_{0}^{2}=\partial_{0}^{2} \sum_{n=-M}^{M} v^{2}(n)
$$

Desain ini memiliki derau pada variansnya. Filter yang ideal memiliki derau output yang sangat kecil. Derau dari varians dapat diperkecil dengan mendefinisikan $\breve{v}$ sebagai sebuah peningkatan sinyal terhadap derau dari input menuju output dengan lokasi nilai $\mathrm{n}=0$.

$$
\breve{\mathrm{v}}=\frac{h(0)}{\sum_{n=-M}^{M} h^{2}(n)}
$$

Dengan mengikuti persamaan 3 hingga persamaan 6 didapatkan 2 operator Laplacian.

$$
\left[\begin{array}{rrr}
-1 & -1 & -1 \\
-1 & 8 & -1 \\
-1 & -1 & -1
\end{array}\right] \quad\left[\begin{array}{rrr}
0 & -1 & 0 \\
-1 & 4 & -1 \\
0 & -1 & 0
\end{array}\right]
$$

Kedua operator tersebut dapat digunakan untuk mendapatkan tepi dari citra tanda tangan [15].

\subsection{Jarak Euclidean}

Metode Jarak adalah salah satu dari banyak cara untuk permasalahan klasifikasi. Euclidean adalah salah satu dari banyak metode jarak yang dapat digunakan untuk mengukur tingkat kemiripan dari citra. Metode jarak Euclidean didapatkan dengan merepresentasikan suatu citra sebagi sebuah vektor titik di dimensi banyak (hyperspace) sehingga dimungkinakn untuk mengukur jarak kemiripan dari 2 citra yang berbeda. Meteode jarak Euclidean dapat dipahami secara bertahap dengan menggambarkan vektor 2 dimensi yang merepresentasikan 2 citra yang berbeda. Kedua vektor ini direpresentasikan dalam diagram kartesian $\mathrm{x}$ dan $\mathrm{y}$. Masing-masing dari vektor tersebut memiliki pada nilai pada bidang $\mathrm{x}$ dan $\mathrm{y}$.

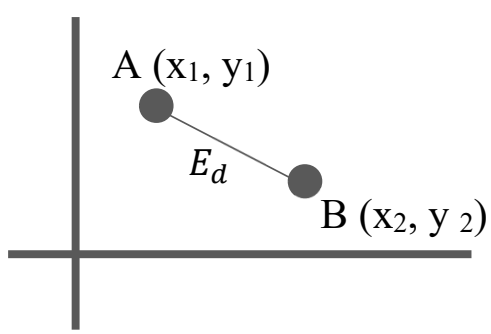

Gambar 1. Penggambaran metode jarak Euclidean

Gambar 1 memperlihatkan bahwaa jarak dari kedua vektor tersebut didapatkan dengan menarik garis diagonal yang lurus dari 1 titik ke titik yang lainnya. Penggambaran ini mirip dengan mencari resultan dari dua buah vektor. Metode ini direpresentasikan secara matematis menjadi

$$
E_{d}=\sqrt{\sum_{1}^{x} \sum_{1}^{y}\left(A_{x, y}-B_{x, y}\right)^{2}}
$$

Jarak dari citra A dan citra B didapatkan dengan mengurangi nilai pixel dari citra $\mathrm{A}$ dan citra $\mathrm{B}$ pada koordinat $\mathrm{x}$ dan y yang sama. Metode ini digunakan karena nilai dari jarak yang didapat adalah jarak yang terdekat yang dapat ditempuh oleh dua titik. Perhitungan dengan jarak Euclidean sangat cocok untuk aplikasi pengolahan citra.

\subsection{Ketetanggaan}

Ketetanggaan adalah metode untuk mengukur validasi dari benar tidaknya suatu citra uji merupakan citra yang mirip dengan citra latih. Konsep ketetanggaan digunakan setelah mendapat nilai jarak dari masing-masing citra uji terhadap citra latih. Nilai dari k untuk ketetanggaan dapat bervariasi tergatung dari berapa banyak macam citra latih yang digunakan.

Penelitian ini menggunakan nilai dari ketetanggaan yang berbeda-beda dimana, $\mathrm{k}=1,2$, dan 3. Apabila menggunakan nilai $\mathrm{k}=1$ maka citra uji dengan jarak terkecil pada citra latih akan didefinisikan sebagai citra yang mirip. Nilai $\mathrm{k}=2$ akan mencari jarak terdekat dari citra uji terhadap 2 citra latih, sehingga didapatkan bahwa citra uji mirip dengan citra latih apabila terdapat 2 citra latih yang memiliki jarak terdekat dengan citra uji. Sedangkan untuk $\mathrm{k}=3$ akan mencari 3 citra latih yang memiliki karak terdekat dengan citra uji. 


\subsection{Pengolahan awal}

Citra yang digunakan memiliki format RGB dengan ukuran resolusi yang berbeda-beda. Penelitian ini memerlukan pengolahan awal untuk mendapatkan basis data citra yang sesuai.

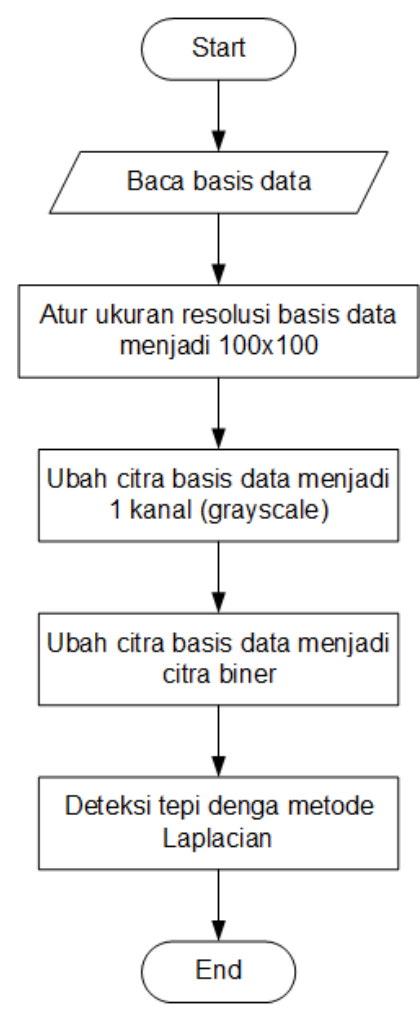

Gambar 2. Diagram alir pemrosesan tahap awal pada citra latih

Pengolahan awal dilakukan pada persiapan citra latih maupun citra uji dimana pengolahan tahap awal terdiri dari 5 tahapan. Langkah pertama yaitu membaca seluruh basis data yang dikumpulkan. Total basis data yang digunakan adalah 200 data yang terdiri dari 10 orang yang berbeda, sehingga masing-masing orang diambil database sebanyak 20 tanda tangan. Dari 20 tanda tangan, diambil masing-masing 5 tanda tangan yang digunakan sebagai citra uji dan sisanya digunakan sebagai citra latih, sehingga hasil akhir konfigurasi yang digunakan adalah 50 tanda tangan sebagai citra uji dan 150 tanda tangan sebagai citra latih. Basis data citra latih terdari dari masing-masing 15 citra tanda tangan dari 10 orang yang berbeda sehingga total citra latih adalah 150 citra, sedangkan basis data citra uji terdiri dari 5 tanda tangan dari 10 orang yang berbeda.

Langkah kedua adalah menyamakan ukuran citra pada basis data menjadi 100x100. Proses ini dilakukan karena setiap citra memiliki ukuran dan resolusi yang berbeda, menyamakan ukuran dilakukan agar proses selanjutnya dapat berjalan lebih mudah dan ukuran 100x100 dipilih agar citra menjadi persegi dengan ukuran yang tidak terlalu besar dan tidak terlalu kecil.

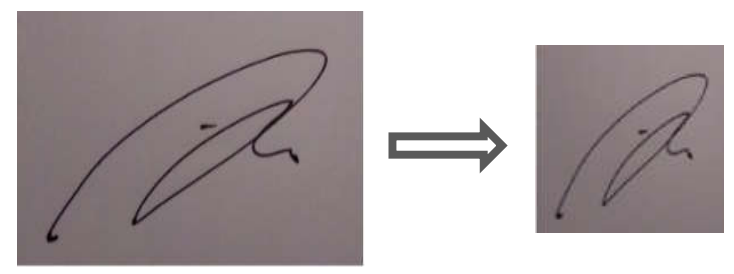

Gambar 3. Konversi citra dengan resolusi $919 \mathrm{x}$ 1280 menjadi $100 x 100$

Langkah ketiga adalah mengubah citra basis data menjadi 1 kanal. Tujuan proses ini adalah mengurangi banyaknya data pada citra RGB agar waktu yang dibutuhkan untuk melakukan pengenalan tanda tangan menjadi lebih cepat. Proses ini dilakukan dengan menggunakan persamaan (1).

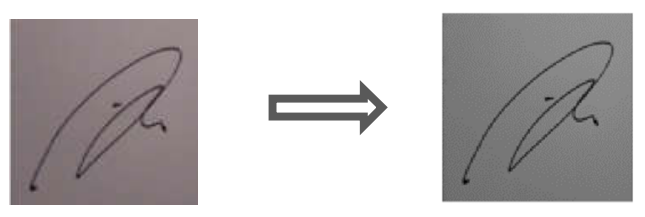

Gambar 4. Proses citra 3 kanal (RGB) menjadi citra 1 kanal (grayscale)

Langkah keempat adalah mengubah citra grayscale menjadi citra biner, hal ini dapat dilakukan dengan menerapkan persamaan (2) dengan nilai th 128. Proses ini dilakukan agar deteksi tepi menggunakna metode Laplacian mendapatkan hasil yang lebih baik.
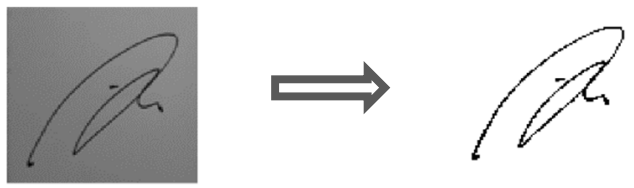

Gambar 5. Proses citra 1 kanal (grayscale) menjadi citra biner

Langkah kelima adalah melakukan proses deteksi tepi dengan metode Laplacian. Langkah ini dilakukan dengan melakukan operasi konvolusi dari citra biner dengan kedua operator Laplacian. 


$$
h(x, y)=b(x, y) * \ell
$$
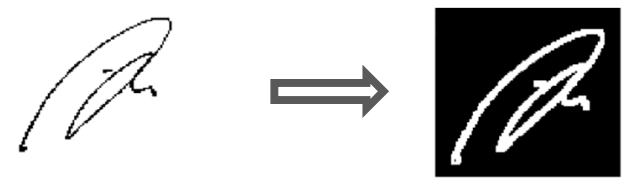

Gambar 6. Citra tepi dengan metode Laplacian

Langkah terakhir adalah meynimpan citra yang telah dideteksi tepi menggunakan metode Laplacian dengan nama data latih untuk citra pada basis data latih dan data uji untuk citra pada basis data uji.

\subsection{Pengelompokan tanda tangan}

Tahap pengelompokan tanda tangan dilakukan dengan mengukur jarak tiap-tiap citra uji terhadap citra latih dengan ketetanggaan yang berbeda-beda yaitu 1,2 , dan 3 .

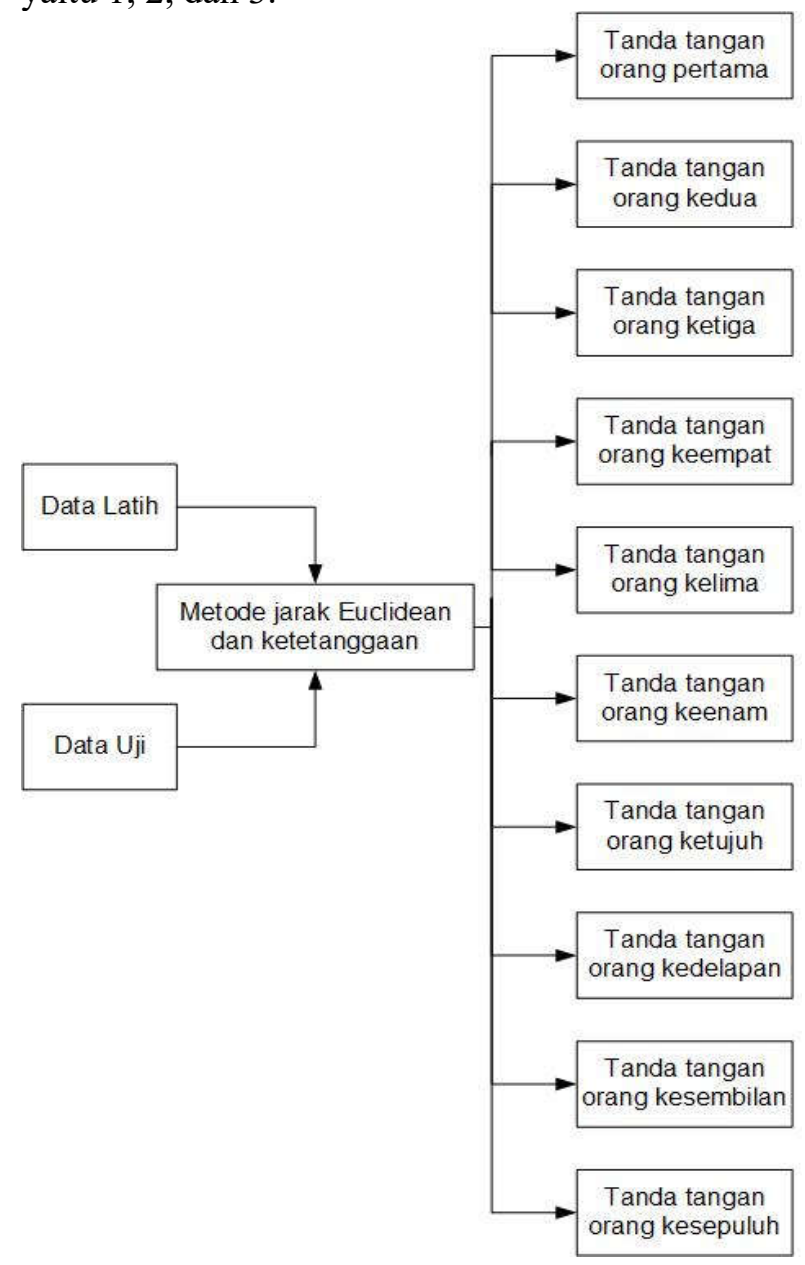

Gambar 7. Blok diagram proses klasifikasi
Proses pengelompokan dilakukan dengan mengukur tingkat kemiripan antara citr uji dan citra latih menggunakan jarak Euclidean. Citra latih dikatakan mirip dengan citra uji jika jarak antara citra uji dan citra latih dekat.

Setelah di ukur dengan jarak Euclidean, dilakukan proses pembobotan terhadap tetangganya. Proses ketetanggaan dilakukan dengan memilih jarak terdekat citra uji terhadap citra latih dengan 1 citra latih untuk 1 ketetanggaan, 2 citra latih terdekat untuk 2 ketetangaan, dan 3 citra latih terdekat untuk 3 ketetangaan.

Hasil dari proses klasifikasi adalah informasi bahwa tiap-tiap citra uji merupakan tanda tangan dari orang pertama, kedua, ketiga, keempat, kelima, dan seterusnya. Masing-masing ketetanggaan akan memiliki perbedaan tingkat kebenaran dalam mengelompokkan. Hasil dari proses klasifikasi merupakan akurasi ketepatan dari tiap-tiap ketetanggaan.

Prosess pengelompokan dilakukan dengan meninjau nilai jarak terdekat dari citra uji terhadap citra latih dan posisinya. Posisi adalah peletakan atau label citra latih dalam sebuah ruang vektor sehingga menunjukkan citra latih untuk tiap-tiap orang. Citra latih untuk orang pertama terletak pada ruang vektor $1-15$. Sebuah citra uji yang memiliki nilai jarak terdekat terhadap citra latih pada ruang vektor citra latih dengan posisi antara 1 - 15 akan dikelompokkan sebagai tanda tangan orang pertama. Citra latih untuk orang kedua terletak pada ruang vektor $16-30$. Sebuah citra uji yang memiliki nilai jarak terdekat terhadap citra latih pada ruang vektor citra latih dengan posisi antara 16 - 30 akan dikelompokkan sebagai tanda tangan orang kedua. Citra latih untuk orang ketiga terletak pada ruang vektor $31-45$. Sebuah citra uji yang memiliki nilai jarak terdekat terhadap citra latih pada ruang vektor citra latih dengan posisi antara 31 - 45 akan dikelompokkan sebagai tanda tangan orang ketiga. Citra latih untuk orang keempat terletak pada ruang vektor $46-60$. Sebuah citra uji yang memiliki nilai jarak terdekat terhadap citra latih pada ruang vektor citra latih dengan posisi antara 46 - 60 akan dikelompokkan sebagai tanda tangan orang keempat. Citra latih untuk orang kelima terletak pada ruang vektor $61-75$. Sebuah 
citra uji yang memiliki nilai jarak terdekat terhadap citra latih pada ruang vektor citra latih dengan posisi antara 61 - 75 akan dikelompokkan sebagai tanda tangan orang kelima. Citra latih untuk orang keenam terletak pada ruang vektor $76-90$. Sebuah citra uji yang memiliki nilai jarak terdekat terhadap citra latih pada ruang vektor citra latih dengan posisi antara 76 - 90 akan dikelompokkan sebagai tanda tangan orang keenam. Citra latih untuk orang ketujuh terletak pada ruang vektor $91-105$. Sebuah citra uji yang memiliki nilai jarak terdekat terhadap citra latih pada ruang vektor citra latih dengan posisi antara 91 - 105 akan dikelompokkan sebagai tanda tangan orang ketujuh. Citra latih untuk orang kedelapan terletak pada ruang vektor $106-120$. Sebuah citra uji yang memiliki nilai jarak terdekat terhadap citra latih pada ruang vektor citra latih dengan posisi antara $106-120$ akan dikelompokkan sebagai tanda tangan orang kedelapan. Citra latih untuk orang kesembilan terletak pada ruang vektor $121-135$. Sebuah citra uji yang memiliki nilai jarak terdekat terhadap citra latih pada ruang vektor citra latih dengan posisi antara 121 - 135 akan dikelompokkan sebagai tanda tangan orang kesembilan. Citra latih untuk orang kesepuluh terletak pada ruang vektor 136 150. Sebuah citra uji yang memiliki nilai jarak terdekat terhadap citra latih pada ruang vektor citra latih dengan posisi antara 136 - 150 akan dikelompokkan sebagai tanda tangan orang kesepuluh. Posisi menunjukkan sebagai label kedekatan citra uji terhadap citra latih dalam ruang vektor, sedangkan nilai adalah nilai jarak citra uji terhadap citra latih merdasarkan pengukuran jarak.

\section{Hasil dan Pembahasan}

Penelitian identifikasi tanda tangan menggunakan deteksi tepi Laplacian menunjukkan hasil yang memuaskan. Penerapan metode Laplacian yang dikombinasikan dengan metode klasifikasi menggunakan jarak Euclidean dan konsep ketetanggaan dalam mengidentifikasi tanda tangan memiliki akurasi yang tinggi di tiap-tiap kelompok. Akurasi ketepatan di tiap-tiap kelompok memiliki hasil yang berbeda-beda untuk tiap-tiap ketetangaan yang digunakan. Hasil percobaan di tiap-tiap kelompok akan dipaparkan.
Tabel 1. Hasil percobaan citra uji orang pertama

\begin{tabular}{|l|r|r|r|r|r|}
\hline \multirow{2}{*}{} & \multicolumn{5}{|c|}{ Citra uji tanda tangan orang pertama } \\
\cline { 2 - 6 } & C1 & C2 & C3 & C4 & \multicolumn{1}{c|}{ C5 } \\
\hline Posisi & 7 & 7 & 7 & 12 & 10 \\
\hline Nilai & 2.094 & 1.952 & 2.037 & 1.914 & 2.162 \\
\hline Posisi & 61 & 8 & 8 & 30 & 59 \\
\hline Nilai & 2.111 & 2.132 & 2.093 & 2.122 & 2.201 \\
\hline Posisi & 70 & 6 & 70 & 11 & 70 \\
\hline Nilai & 2.143 & 2.211 & 2.149 & 2.157 & 2.232 \\
\hline
\end{tabular}

Hasil dari pengelompokan tanda tangan orang pertama dapat diamati pada Tabel 1. Terdapat 5 citra uji yang di identifikasikan berdasarkan posisi di ruang vektor dan nilai jarak terdekat. Terdapat 15 citra latih untuk masing-masing orang. Posisi menunjukkan label bahwa citra uji memiliki jarak terdekat dengan citra latih pada ruang vektor berapa. Apabila citra latih 1 berada pada posisi $1-15$ dari 150 citra latih, dapat dikatakan bahwa $\mathrm{C} 1$ atau citra uji kelompok 1 memiliki kedekatan dengan citra latih ke -7 dengan nilai jaraknya 2.094 sehingga citra uji 1 dikelompokkan dengan citra tanda tangan orang pertama berdasarkan labelnya. C1 merupakan citra uji untuk orang pertama, sehingga apabila keluaran sistem berdasarkan label posisi menunjukkan angka 1 - 15 maka sistem benar dalam mengenali tanda tangan. Data lain menunjukkan bahwa $\mathrm{C} 1$ memiliki kedekatan dengan citra latih pada posisi 61 dengan nilai 2.111 sedangkan posisi 61 adalah citra latih untuk orang kelima sehingga $\mathrm{C} 1$ dikelompokkan dengan tanda tangan orang kelima dimana seharusnya $\mathrm{C} 1$ adalah tanda tangan orang pertama sehingga data kedua bernilai salah. Data ketiga menunjukkan bahwa citra uji $\mathrm{C} 1$ memiliki kedekatan terhadap citra latih pada posisi ruang vektor 70 . Ruang vektor $60-75$ merupakan ruang vektor orang kelima sehingga berdasarkan percobaan ketiga, citra uji C1 dikenali sebagai citra tanda tangan orang kelima. Hal ini merupakan kesalahan karena citra latih $\mathrm{C} 1$ merupakan tanda tangan orang pertama.

Setelah di uji sebanyak 3 kali dilakukan pembobotan terhadap ketetanggaan. Ketetanggaan 1 menunjukkan bahwa citra uji dikelompokkan berdasarkan 1 citra latih. Ketetanggaan 2 menunjukkan bahwa citra uji dikelompokkan berdasarkan 2 citra latih. Apabila terdapat 2 tetangga dengan hasil yang berbeda, maka sistem akan mengeluarkan nilai salah. Ketetanggaan 3 akan dikelompokkan berdasarkan 3 citra latih terdekat, apabila terdapat 2 tetangga dengan posisi 
yang benar maka sistem akanmenghasilkan nilai benar berdasarkan posisinya, namun bila 2 tetangga salah maka sistem akan salah dalam mengelompokkan. Berdasarkan Tabel 1 dapat diamati bahwa ketetanggaan 1 memiliki tingkat ketepatan sebesar $100 \%$, ketetanggaan 2 memiliki akurasi $40 \%$ dan ketetanggan 3 memiliki akurasi $60 \%$ berdasarkan letak posisi dan nilai kedekatan citra.

Tabel 2. Hasil percobaan citra uji orang kedua

\begin{tabular}{|l|r|r|r|r|r|}
\hline \multirow{2}{*}{} & \multicolumn{5}{|c|}{ Citra uji tanda tangan orang kedua } \\
\cline { 2 - 6 } & C6 & \multicolumn{1}{|c|}{ C7 } & \multicolumn{1}{c|}{ C8 } & \multicolumn{1}{c|}{ C9 } & C10 \\
\hline Posisi & 30 & 30 & 30 & 30 & 24 \\
\hline Nilai & 1.992 & 1.990 & 1.805 & 1.843 & 1.915 \\
\hline Posisi & 18 & 21 & 26 & 38 & 16 \\
\hline Nilai & 2.175 & 2.041 & 1.883 & 2.004 & 1.921 \\
\hline Posisi & 24 & 18 & 38 & 27 & 17 \\
\hline Nilai & 2.182 & 2.148 & 1.934 & 2.088 & 1.981 \\
\hline
\end{tabular}

Hasil dari pengelompokan tanda tangan orang kedua dapat diamati pada Tabel 2. Posisi untuk citra latih orang kedua terdapat pada ruang vektor $16-$ 30 sehingga hasil dari identifikasi dengan posisi di antara 16 - 30 adalah benar dan posisi selain itu adalah salah. Tabel 2 menunjukkan bahwa akurasi untuk ketetanggaan 1 pada kelompok percobaan orang kedua adalah $100 \%$, ketetanggaan 2 adalah $80 \%$ dan ketetanggaan 3 adalah $100 \%$.

Tabel 3. Hasil percobaan citra uji orang ketiga

\begin{tabular}{|l|r|r|r|r|r|}
\hline \multirow{2}{*}{} & \multicolumn{6}{|c|}{ Citra uji tanda tangan orang ketiga } \\
\cline { 2 - 6 } & $\mathrm{C} 11$ & $\mathrm{C} 12$ & $\mathrm{C} 13$ & $\mathrm{C} 14$ & \multicolumn{1}{c|}{ C15 } \\
\hline Posisi & 42 & 43 & 44 & 39 & 40 \\
\hline Nilai & 2.227 & 2.468 & 2.635 & 2.173 & 2.077 \\
\hline Posisi & 30 & 45 & 16 & 30 & 33 \\
\hline Nilai & 2.236 & 2.569 & 2.669 & 2.177 & 2.109 \\
\hline Posisi & 26 & 70 & 28 & 40 & 39 \\
\hline Nilai & 2.307 & 2.593 & 2.680 & 2.203 & 2.117 \\
\hline
\end{tabular}

Hasil dari pengelompokan tanda tangan orang ketiga dapat diamati pada Tabel 3. Posisi untuk citra latih orang ketiga terdapat pada ruang vektor 31 - 45 sehingga hasil dari identifikasi dengan posisi di antara 31 - 45 adalah benar dan posisi selain itu adalah salah. Tabel 3 menunjukkan bahwa akurasi untuk ketetanggaan 1 pada kelompok percobaan orang ketiga adalah $100 \%$, ketetanggaan 2 adalah $40 \%$ dan ketetanggaan 3 adalah $60 \%$.
Tabel 4. Hasil percobaan citra uji orang keempat

\begin{tabular}{|l|r|r|r|r|r|}
\hline \multirow{2}{*}{} & \multicolumn{5}{|c|}{ Citra uji tanda tangan orang keempat } \\
\cline { 2 - 6 } & C16 & C17 & C18 & C19 & C20 \\
\hline Posisi & 50 & 50 & 50 & 57 & 52 \\
\hline Nilai & 1.941 & 2.192 & 2.197 & 2.137 & 2.168 \\
\hline Posisi & 55 & 33 & 57 & 30 & 50 \\
\hline Nilai & 1.943 & 2.225 & 22.14 & 2.199 & 2.212 \\
\hline Posisi & 57 & 30 & 30 & 49 & 54 \\
\hline Nilai & 2.064 & 2.249 & 2.238 & 2.201 & 2.218 \\
\hline
\end{tabular}

Tabel 4 merupakan hasil dari pengelompokan tanda tangan orang keempat. Posisi untuk citra latih orang keempat terdapat pada ruang vektor $46-60$. Hasil dari identifikasi dengan posisi di antara 46 60 adalah benar dan posisi selain itu adalah salah. Tabel 4 menunjukkan bahwa akurasi untuk ketetanggaan 1 pada kelompok percobaan orang keempat adalah $100 \%$, ketetanggaan 2 adalah $60 \%$ dan ketetanggaan 3 adalah $80 \%$.

Tabel 5. Hasil percobaan citra uji orang kelima

\begin{tabular}{|l|r|r|r|r|r|}
\hline \multirow{2}{*}{} & \multicolumn{6}{|c|}{ Citra uji tanda tangan orang kelima } \\
\cline { 2 - 6 } & C21 & C22 & C23 & C24 & C25 \\
\hline Posisi & 72 & 66 & 69 & 27 & 66 \\
\hline Nilai & 2.167 & 2.083 & 2.332 & 2.256 & 2.106 \\
\hline Posisi & 69 & 57 & 72 & 57 & 74 \\
\hline Nilai & 2.229 & 2.211 & 2.365 & 2.259 & 2.343 \\
\hline Posisi & 63 & 69 & 71 & 69 & 72 \\
\hline Nilai & 2.246 & 2.230 & 2.398 & 2.268 & 2.347 \\
\hline
\end{tabular}

Hasil dari pengelompokan tanda tangan orang kelima dapat diamati pada Tabel 5. Posisi untuk citra latih orang kelima terdapat pada ruang vektor 61 - 75 sehingga hasil dari identifikasi dengan posisi di antara 61 - 75 adalah benar dan posisi selain itu adalah salah. Tabel 5 menunjukkan bahwa akurasi untuk orang kelima ketetanggaan 1 adalah 96\%, ketetanggaan 2 adalah $60 \%$ dan ketetanggaan 3 adalah $60 \%$.

Tabel 6. Hasil percobaan citra uji orang keenam

\begin{tabular}{|l|r|r|r|r|r|}
\hline \multirow{2}{*}{} & \multicolumn{5}{|c|}{ Citra uji tanda tangan orang keenam } \\
\cline { 2 - 6 } & C26 & C27 & C28 & C29 & C30 \\
\hline Posisi & 81 & 81 & 83 & 88 & 81 \\
\hline Nilai & 1.900 & 1.633 & 1.920 & 1.701 & 1.941 \\
\hline Posisi & 88 & 88 & 88 & 79 & 79 \\
\hline Nilai & 1.955 & 1.883 & 1.953 & 1.759 & 2.061 \\
\hline Posisi & 89 & 90 & 79 & 91 & 88 \\
\hline Nilai & 2.037 & 1.946 & 1.971 & 1.906 & 2.080 \\
\hline
\end{tabular}


Hasil dari pengelompokan tanda tangan orang keenam dapat diamati pada Tabel 6. Posisi untuk citra latih orang keenam terdapat pada ruang vektor 76 - 90 sehingga hasil dari identifikasi dengan posisi di antara 76 - 90 adalah benar dan posisi selain itu adalah salah. Tabel 6 menunjukkan bahwa akurasi untuk orang keenam ketetanggaan 1 adalah $100 \%$, ketetanggaan 2 adalah $100 \%$ dan ketetanggaan 3 adalah $100 \%$.

Tabel 7. Hasil percobaan citra uji orang ketujuh

\begin{tabular}{|l|r|r|r|r|r|}
\hline \multirow{2}{*}{} & \multicolumn{5}{|c|}{ Citra uji tanda tangan orang ketujuh } \\
\cline { 2 - 6 } & C31 & C32 & C33 & C34 & C35 \\
\hline Posisi & 91 & 94 & 91 & 95 & 91 \\
\hline Nilai & 1.737 & 1.505 & 1.561 & 1.458 & 1.404 \\
\hline Posisi & 94 & 92 & 92 & 91 & 92 \\
\hline Nilai & 1.739 & 1.563 & 1.580 & 1.478 & 1.461 \\
\hline Posisi & 92 & 91 & 89 & 102 & 94 \\
\hline Nilai & 1.750 & 1.615 & 1.598 & 1.495 & 1.509 \\
\hline
\end{tabular}

Hasil dari pengelompokan tanda tangan orang ketujuh dapat diamati pada Tabel 7. Posisi untuk citra latih orang ketujuh terdapat pada ruang vektor 91 - 105 sehingga hasil dari identifikasi dengan posisi di antara 91 - 105 adalah benar dan posisi selain itu adalah salah. Tabel 7 menunjukkan bahwa akurasi untuk orang ketujuh ketetanggaan 1 adalah $100 \%$, ketetanggaan 2 adalah $100 \%$ dan ketetanggaan 3 adalah $100 \%$.

Tabel 8. Hasil percobaan citra uji orang kedelapan

\begin{tabular}{|l|r|r|r|r|r|}
\hline \multirow{2}{*}{} & \multicolumn{6}{|c|}{ Citra uji tanda tangan orang kedelapan } \\
\cline { 2 - 6 } & C36 & C37 & \multicolumn{1}{|c|}{ C38 } & C39 & \multicolumn{1}{c|}{ C40 } \\
\hline Posisi & 107 & 120 & 111 & 107 & 120 \\
\hline Nilai & 1.664 & 1.475 & 1.098 & 1.617 & 1.713 \\
\hline Posisi & 117 & 109 & 110 & 100 & 117 \\
\hline Nilai & 1.696 & 1.581 & 1.589 & 1.732 & 1.736 \\
\hline Posisi & 119 & 115 & 109 & 116 & 107 \\
\hline Nilai & 1.722 & 1.607 & 1.589 & 1.753 & 1.772 \\
\hline
\end{tabular}

Hasil dari pengelompokan tanda tangan orang kedelapan dapat diamati pada Tabel 8. Posisi untuk citra latih orang kedelapan terdapat pada ruang vektor 106 - 120 sehingga hasil dari identifikasi dengan posisi di antara 106 - 120 adalah benar dan posisi selain itu adalah salah. Tabel 8 menunjukkan bahwa akurasi untuk orang kedelapan ketetanggaan 1 adalah $100 \%$, ketetanggaan 2 adalah $80 \%$ dan ketetanggaan 3 adalah $100 \%$.
Tabel 9. Hasil percobaan citra uji orang kesembilan

\begin{tabular}{|l|r|r|r|r|r|}
\hline \multirow{2}{*}{} & \multicolumn{6}{|c|}{ Citra uji tanda tangan orang kesembilan } \\
\cline { 2 - 6 } & C41 & \multicolumn{1}{c|}{ C42 } & C43 & C44 & \multicolumn{1}{c|}{ C45 } \\
\hline Posisi & 123 & 124 & 123 & 123 & 95 \\
\hline Nilai & 1.870 & 1.801 & 1.905 & 1.885 & 2.043 \\
\hline Posisi & 122 & 121 & 95 & 95 & 122 \\
\hline Nilai & 1.985 & 1.830 & 2.051 & 1.977 & 2.054 \\
\hline Posisi & 95 & 92 & 92 & 122 & 91 \\
\hline Nilai & 2.004 & 1.841 & 2.061 & 1.978 & 2.067 \\
\hline
\end{tabular}

Hasil dari pengelompokan tanda tangan orang kesembilan dapat diamati pada Tabel 9. Posisi untuk citra latih orang kesembilan terdapat pada ruang vektor 121 - 135 sehingga hasil dari identifikasi dengan posisi di antara 121 - 135 adalah benar dan posisi selain itu adalah salah. Tabel 9 menunjukkan bahwa akurasi untuk orang kesembilan dengan ketetanggaan 1 adalah $90 \%$, ketetanggaan 2 adalah $40 \%$ dan ketetanggaan 3 adalah $60 \%$.

Tabel 10. Hasil percobaan citra uji orang kesepuluh

\begin{tabular}{|l|r|r|r|r|r|}
\hline \multirow{2}{*}{} & \multicolumn{6}{|c|}{ Citra uji tanda tangan orang kesepuluh } \\
\cline { 2 - 6 } & C46 & C47 & C48 & C49 & C50 \\
\hline Posisi & 107 & 148 & 148 & 148 & 148 \\
\hline Nilai & 2.370 & 2.341 & 2.208 & 2.010 & 1.940 \\
\hline Posisi & 96 & 97 & 98 & 98 & 96 \\
\hline Nilai & 2.403 & 2.413 & 2.495 & 2.390 & 2.302 \\
\hline Posisi & 97 & 98 & 97 & 107 & 107 \\
\hline Nilai & 2.438 & 2.471 & 2.496 & 2.404 & 2.311 \\
\hline
\end{tabular}

Hasil dari pengelompokan tanda tangan orang kesepuluh dapat diamati pada Tabel 10. Posisi untuk citra latih orang kesepuluh terdapat pada ruang vektor $136-150$ sehingga hasil dari identifikasi dengan posisi di antara $136-150$ adalah benar dan posisi selain itu adalah salah. Tabel 10 menunjukkan bahwa akurasi untuk orang kesepuluh dengan ketetanggaan 1 adalah $90 \%$, ketetanggaan 2 adalah $0 \%$ dan ketetanggaan 3 adalah $0 \%$.

Total dari hasil akurasi untuk ketetanggaan 1,2 dan 3 di tiap-tiap percobaan di hitung kembali untuk mendapatkan akurasi total untuk tiap-tiap ketetanggaan dengan menggunakan matriks konfusi. Matriks konfusi akan memperlihatkan kinerja sistem pada kebenaran pembacaan dan kesalahan pembacaan sehingga dapat digunakan 
untuk mengukur akurasi total.

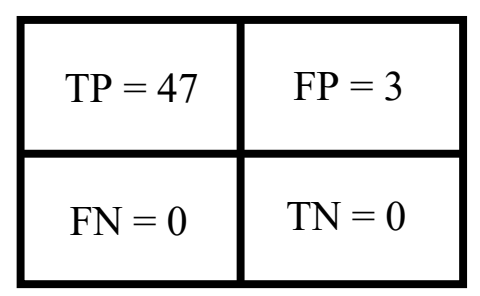

Gambar 8. Matriks konfusi untuk ketetanggan 1

Matriks konfusi untuk ketetanggaan 1 dapat diamati pada Gambar 8. Hasil dari matriks konfusi adalah elemen true positive bernilai 47 , false positive bernilai 1 , false negative bernilai 0 , dan true negative bernilai 0 . Dari hasil tersebut didapatkan hasil bahwa nilai akurasi untuk ketetanggaan 1 adalah 94\%.

\begin{tabular}{|c|c|}
\hline $\mathrm{TP}=30$ & $\mathrm{FP}=20$ \\
\hline $\mathrm{FN}=0$ & $\mathrm{TN}=0$ \\
\hline
\end{tabular}

Gambar 9. Matriks konfusi untuk ketetanggan 2

Matriks konfusi untuk ketetanggaan 2 dapat diamati pada Gambar 9. Hasil dari matriks konfusi adalah elemen true positive bernilai 30 , false positive bernilai 20 , false negative bernilai 0 , dan true negative bernilai 0 . Dari hasil tersebut didapatkan hasil bahwa nilai akurasi untuk ketetanggaan 1 adalah $60 \%$.

\begin{tabular}{|c|c|}
\hline $\mathrm{TP}=37$ & $\mathrm{FP}=13$ \\
\hline $\mathrm{FN}=0$ & $\mathrm{TN}=0$ \\
\hline
\end{tabular}

Gambar 10. Matriks konfusi untuk ketetanggan 3

Matriks konfusi untuk ketetanggaan 3 dapat diamati pada Gambar 10. Hasil dari matriks konfusi adalah elemen true positive bernilai 37, false positive bernilai 13 , false negative bernilai 0 , dan true negative bernilai 0 . Dari hasil tersebut didapatkan hasil bahwa nilai akurasi untuk ketetanggaan 1 adalah $74 \%$.

\section{Kesimpulan}

Berdasarkan hasil dari penelitian yang telah dilakukan, dapat disimpulkan bahwa implementasi metode deteksi tepi Laplacian dan jarak Euclidean untuk identifikasi tanda tangan mendapatkan hasil yang memuaskan. Akurasi untuk 1 ketetanggaan adalah $94 \%$, akurasi 2 ketetanggaan adalah $60 \%$, dan akurasi untuk 3 ketetanggaan adalah 74\%. Dari hasil tersebut, identifikasi tanda tangan paling akurat menggunakan 1 ketetangaan.

\section{Daftar Pustaka}

[1] A. K. Jain, A. A. Ross, and K. Nandakumar, Introduction to Biometrics. Springer.

[2] I. V. Anikin and E. S. Anisimova, "Handwritten signature recognition method based on fuzzy logic," Dyn. Syst. Mech. Mach., pp. 1-5, 2016.

[3] V. Smejkal and J. Kodl, "Dynamic Biometric Signature - an Effective Alternative for Electronic Authentication," Adv. Technol. Innov., vol. 3, pp. 166-178, 2017.

[4] P. Porwik and T. Para, "Some Handwritten Signature Parameters in Biometric Recognition Process," Int. Confrence Inf. Technol. Interfaces, pp. 185-190, 2007.

[5] V. A. Bharadi and H. B. Kekre, "Off-Line Signature Recognition Systems," Int. J. Comput. Appl., vol. 1, no. 27, pp. 48-56, 2010.

[6] J. V. Tahapary, "Keabsahan Tanda Tangan Elektronik Sebagai Alat Bukti yang Sah Ditinjau dalam Hukum Acara Perdata," 2011.

[7] H. H. Soepraptomo, "Kejahatan Komputer dan Siber Serta Antisipasi Pengaturan Pencegahannya di Indonesia," 2001.

[8] N. Iriyanti, "Tinjauan Kekuatan Pembuktian Digital Signature dalam Sengketa Perdata Ditinjau dari UU No 11 Tahun 2008 Tentang Informasi dan Transaksi Elektronik," 2009.

[9] M. Farid, "Alat Bukti Elektronik dalam Proses Pembuktian Perkara Perdata di Pengadilan," 2015.

[10] A. Edi, "Implikasi Adanya Pemalsuan Tanda Tangan dalam Akta Jual Beli Tanah yang Dilakukan oleh PPAT," 2017.

[11] H. Santoso, "Identifikasi tanda tangan dengan deteksi tepi dan koefisien korelasi," 
PROXIES, vol. 1, no. 2, pp. 68-74, 2017.

[12] A. Karouni, B. Daya, and S. Bahlak, "Offline signature recognition using neural networks approach," Procedia Comput. Sci., vol. 3, pp. 155-161, 2011.

[13] E. R. Kuswandi and N. Fadillah, "Perbandingan Metode Robert dan Metode Prewitt Untuk Deteksi Tepi pada Citra Tanda Tangan," J. Nas. Inform. dan Teknol. Jar., vol. 3, no. 2, pp. 155-158, 2019.

[14] M. S. Nixon and A. S. Aguado, Feature Extraction \& Image Processing for Computer Vision. Elsevier, 2012.

[15] X. Wang, "Laplacian Operator-Based Edge Detectors," IEEE Trans. Pattern Anal. Mach. Intell., vol. 29, no. 5, pp. 886-890, 2007.

\section{Biodata Penulis}

Mas Aly Afandi, menyelesaikan D4 di Politeknik Elektronika Negeri Surabaya (PENS), jurusan teknik elektro dan lulus pada tahun 2015. Pendidikan S2 di Institut Teknologi Sepuluh Nopember (ITS), jurusan teknik elektro dan lulus pada tahun 2018. Minat penelitian pada ruang lingkup pengolahan citra, kontrol, robotika, kecerdasan buatan, dan sistem cerdas.

Sevia Indah Purnama, menyelesaikan D4 di Politeknik Negeri Malang (POLINEMA), mengambil jurusan teknik elektro dan lulus pada tahun 2014. Pendidikan S2 di Institut Teknologi Sepuluh Nopember (ITS), jurusan teknik elektro dan lulus pada tahun 2019. Minat penelitian pada ruang lingkup signal processing, robotika, sistem tertanam, kecerdasan buatan dan sistem cerdas.

Risa Farrid Cristianti, meyelesaikan S1 di Universitas Katolik Soegijapranata, mengambil jurusan teknik elektro dan lulus pada tahun 2001. Pendidikan S2 di Universitas Gajah Mada (UGM), mengambil jurusan teknik instrumentasi industri dan lulus pada tahun 2007. Minat penelitian pada ruang lingkup sistem cerdas, sistem sensor cerdas, instrumentasi elektronika dan robotika. 